\title{
A Comparison Study of Soil Samples from Sinai Province in Egypt by Using X-Ray Diffraction and Gamma-Ray Analysis
}

\author{
Shadiah S. Baz \\ Physics Department, Girls Faculty of Science, King Abdulaziz University, Jeddah, Saudi Arabia \\ Email: SBAZ@KAU.edu.Sa
}

Received 14 March 2015; accepted 24 April 2015; published 29 April 2015

Copyright (C) 2015 by author and Scientific Research Publishing Inc. This work is licensed under the Creative Commons Attribution International License (CC BY). http://creativecommons.org/licenses/by/4.0/ (c) (7) Open Access

\section{Abstract}

Ten soil samples from Jabal Al Qur, Wadi Baba, and Wadi Sieh in Sinai, Egypt, were analyzed by XRD spectroscopy. The XRD spectroscopy results indicate that the major, minor and trace constituents varied from one sample to another. Samples were also analyzed by HPGe gamma spectrometer to determine the activity concentration of $\mathrm{U}-238$, Th-232 series and $\mathrm{K}-40$. The concentrations for ${ }^{238} \mathrm{U}$ ranged from 57.03 to $4220.41 \mathrm{~Bq} / \mathrm{kg}$ with an average $1110.75 \mathrm{~Bq} / \mathrm{kg}$, for ${ }^{232} \mathrm{Th}$, ranged from 13.55 to130.46 Bq/ $\mathrm{kg}$ with an average $71.85 \mathrm{~Bq} / \mathrm{Kg}$. The concentrations for ${ }^{40} \mathrm{~K}$ were in the range from 12.18 to $948.93 \mathrm{~Bq} / \mathrm{kg}$ with an average value $457.09 \mathrm{~Bq} / \mathrm{kg}$. The average activity concentration values of ${ }^{226} \mathrm{Ra},{ }^{232} \mathrm{Th}$, and ${ }^{40} \mathrm{~K}$, in all the collected samples were higher than the world average. The radium equivalent $\left(R_{e q}\right)$, absorbed dose rate $\left(D_{R}\right)$, the effective dose rate $\left(D_{\text {eff }}\right)$, and hazard indices resulted due to the natural radionuclides in soil are also calculated. The Results show that the study area is not safe for human and environments.

\section{Keywords}

Sinai Soil, X-Ray Diffraction, Natural Radioactivity Concentration, Chemical Constituent, Diffract Meter

\section{Introduction}

Measurement of the concentrations of natural radionuclides in soil give information's on the natural radionuclide sources. Beck suggested that $50 \%-80 \%$ of the total gamma flux at the earth's surface arises from ${ }^{40} \mathrm{~K}$ and ${ }^{232} \mathrm{Th},{ }^{238} \mathrm{U}$ series [1]. Knowledge of the distribution of these radionuclides in the environment is essential in the sense of controlling radiation levels [2]. Further, data on natural radiation are important for designing rules and 
regulations for radiation protection purposes [3]. The variation in data for various locations is due to the differences in the geology of sampling sites [3]. So several authors have studied the levels of natural background radiation by analysis of radionuclide concentration in soil samples, see e.g.: [4]-[9]. These studies pointed out that the effective gamma radiation levels were generally in the range of $10-200 \mathrm{nGyh}^{-1}$ with a mean of $60 \mathrm{nGyh}^{-1}[10]$.

$\mathrm{X}$-Ray Diffraction (XRD) is a non-destructive analytical technique. When X-ray strikes on a crystal surface at an angle $\theta$, a portion of the $\mathrm{X}$-ray is scattered by a layer of atoms at the surface. Un-scattered $\mathrm{X}$-ray penetrates to the second layer of atoms where again a fraction is scattered. The remaining $\mathrm{X}$-ray passes to the third layer until the energy of the X-ray is dissipated completely. An X-ray detector measures the cumulative effect of the scattering beams. The $\mathrm{X}$-ray appear to be reflected from the crystal only if the angle of incidence satisfies the condition of Bragg Equation, $\mathrm{n} \lambda=2 \mathrm{~d}_{\mathrm{hkl}} \sin \theta$. The $\mathrm{X}$-ray pattern shows the peaks at various angles of incidence [11].

The objectives of the present study are to determine some metal concentrations and measure the natural radioactivity levels of ${ }^{226} \mathrm{Ra},{ }^{232} \mathrm{Th}$, and ${ }^{40} \mathrm{~K}$ in the soil samples taken from selected places in Sinai region, Egypt, also to assess the radiological Hazard indices in air and to compare the results with international levels. Radionuclides ${ }^{226} \mathrm{Ra}$, ${ }^{232} \mathrm{Th}$ and ${ }^{40} \mathrm{~K}$ were measured with a well-type gamma-ray detector, and metal concentrations were determined by X-Ray diffraction, patterns were recorded using X'Pert PRO Powder X-Ray Diffraction with $\mathrm{Cu} \mathrm{K} \alpha$ radiation $(\lambda=0.1542 \mathrm{~nm})$, Ni-filter and general area detector. The data generated in this study provide baseline values of natural radioactivity in Sinai soils and may be useful for authorities in the implementation of radiation protection standards for the general population in the country as well as to plan and conduct further studies on this issue.

\section{Analytical Technique}

\subsection{Study Area}

Sinai can be divided into three areas: The northern region consists of sand dunes and fossil beaches formed by the changing levels of the Mediterranean Sea during the glacial periods two million years ago. The landscape is flat and uniform, interrupted by sand and limestone hills. The central area with limestone dating from the Tertiary Period is the highlands extend towards the south. The third area consists of granite and volcanic rocks. Limestone and sandstone sediments are replaced by granite and basalt. Both rocks are produced by volcanic activity on the bottom of the ocean. Ten soil samples were collected from different areas of Sinai; Jabal Al Qur $\left(28^{\circ} 49^{\prime} 46.06^{\prime \prime} \mathrm{N}-33^{\circ} 17^{\prime} 45.41 " \mathrm{E}\right)$ is located inland south-east of Sinai and consists of granite and volcanic rocks, Limestone and sandstone sediments. Wadi Baba $\left(28^{\circ} 58^{\prime} 30.80^{\prime \prime} \mathrm{N}-33^{\circ} 17^{\prime} 31.47^{\prime \prime E}\right)$ is a low altitude system located inland south-east of Wadi Gharandel. The system consists of several smaller interconnecting wadis with gravel beds and high rise sandstone cliffs either side. Wadi Sieh $\left(29^{\circ} 03^{\prime} 27.28^{\prime \prime} \mathrm{N}-33^{\circ} 26^{\prime} 14.84 " \mathrm{E}\right)$ is located further inland north-east of Wadi Baba; the wadi has a sandy bed with sandstone canyons rising either side, as shown in Figure 1, (www.bedawi.com/Sinai_EN.html).

\subsection{Sample Collection, Preparation and Measuring Methods}

Ten soil samples were collected from different areas of Sinai; Jabal Al Qur, Wadi Baba and Wadi Sieh. These collected samples have different Descriptions as shown in Table 1. Samples were grounded and passed through a $1 \mathrm{~mm}$ sieve and dried to $95^{\circ} \mathrm{C}$ for 24 hours in order not to lose the volatile polonium or cesium. Ten gm of the dried samples were analyzed by XRD model X'Pert PRO powder diffract meter equipped with Cu anode, for the chemical and mineral composition. The X-ray source used in this research has a wavelength of $1.540562 \AA$. The diffract grams were recorded in the $2 \theta$ range of $0.5^{\circ}-70^{\circ}$ with step size of $0.02 \AA$ and a step time of $0.60 \mathrm{~s}$. For radiometric analysis, the dried fine grained samples were packed in polyethylene Marinelli beaker for gamma spectroscopy and then stored for four weeks to reach secular equilibrium between radium-226 and thorium-232 and their progenies. The samples were analyzed non-destructively, using gamma-ray spectrometry with Canberra high purity germanium (HPGe) coaxial detector with relative efficiency of 25\% and FWHM $2.0 \mathrm{keV}$ at 1332 $\mathrm{keV}$ of ${ }^{60} \mathrm{Co}$. Genie 2000 basic spectroscopic software was installed in the computer for data acquisition and analysis. The system was calibrated for energy and absolute efficiency. The measurements were done for a time period of 82,800 sec. An empty polyethylene Marinelli beaker was placed in the detection system for the same time period of measurement, in order to collect the background count rates. Then, each sample was measured during the same accumulating time. 


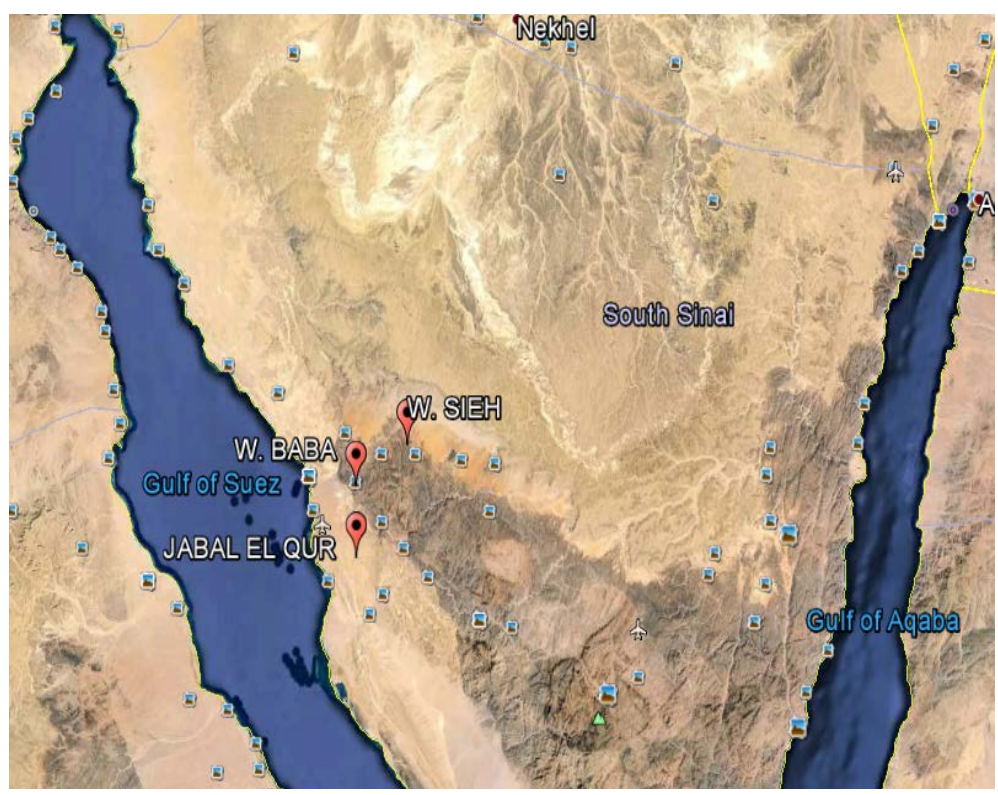

Figure 1. Location map of the collected samples.

Table 1. Description of collected samples.

\begin{tabular}{cc}
\hline Sample Code & Description \\
\hline Soil 1 & Sandy dolostone, medium hard to hard, grey. \\
Soil 2 & Siltstone with ferruginous Shale, mainly red and grey. \\
Soil 3 & Sandstone, red, medium hard with pebbles. \\
Soil4 & Gibbsite, soft, brownish yellow. \\
Soil 5 & Gibbsite-bearing shale, soft to medium hard, yellowish brown. \\
Soil 6 & Siltstone, soft to medium hard, brown. \\
Soil 7 & Gibbsite, soft, brown. \\
Soil 8 & Ferruginous siltstone soft to medium hard. \\
Soil 9 & Conglomeratic sandstone, pale brown, medium hard. \\
Soil 10 & Clay stone, creamy, soft to medium hard. \\
\hline
\end{tabular}

\section{Calculations}

\subsection{Activity Concentrations}

The concentration of ${ }^{226} \mathrm{Ra}$ was determined from the average concentration of gamma-ray lines of energies $351.87 \mathrm{keV}$ of ${ }^{214} \mathrm{~Pb}$ and $609.31 \mathrm{keV}$ of ${ }^{214} \mathrm{Bi}$ (since there is secular radioactivity equilibrium in ${ }^{226} \mathrm{Ra}$ series). Also, the concentration of ${ }^{232} \mathrm{Th}$, which it is in secular radioactivity equilibrium with its short half-life daughters, was determined from the average concentrations of ${ }^{228} \mathrm{Ac}$ (with gamma-ray line $911.16 \mathrm{kev}$ ) and of ${ }^{208} \mathrm{Tl}$ (with gamma-ray line $583.10 \mathrm{keV}$ ). The analysis of ${ }^{40} \mathrm{~K}$ concentrations was based on its single peak in the spectrum at energy $1460.80 \mathrm{kev}$. The activity concentrations "As" of the natural radionuclides in the measured samples were computed using the following relation [12]:

$$
\operatorname{As}(\mathrm{Bq} / \mathrm{kg})=\mathrm{Ca} / \varepsilon \operatorname{PrMs}
$$

where: Ca is the net gamma counting rate (counts per second), $\varepsilon$ the detector efficiency of the specific $\gamma$-ray, $\operatorname{Pr}$ the absolute transition probability of Gamma-decay and Ms the mass of the sample (kg). 


\subsection{Radiological Hazard Indices Radium Equivalent Activity $\mathrm{Ra}_{\mathrm{eq}}(\mathrm{Bq} / \mathrm{kg})$}

To assess the real activity level of ${ }^{226} \mathrm{Ra},{ }^{232} \mathrm{Th}$ and ${ }^{40} \mathrm{~K}$ in soil, a common radiological index has been defined in terms of radium equivalent activity $\left(\mathrm{Ra}_{\mathrm{eq}}\right)$ in $\mathrm{Bq} / \mathrm{kg}$ can be used, provides a very useful guideline in regulating the safety standards in radiation protection for a human population. The index was calculated through the following formula is based on the assumption that $370 \mathrm{~Bq} / \mathrm{kg}$ of ${ }^{226} \mathrm{Ra}, 259 \mathrm{~Bq} / \mathrm{kg}$ of ${ }^{232} \mathrm{Th}$ and $4810 \mathrm{~Bq} / \mathrm{kg}$ of ${ }^{40} \mathrm{~K}$ produce the same gamma-ray dose rate [10]:

$$
\mathrm{Ra}_{\text {eq }}(\mathrm{Bq} / \mathrm{kg})=\mathrm{C}_{\mathrm{Ra}}+1.43 \mathrm{C}_{\mathrm{Th}}+0.077 \mathrm{C}_{\mathrm{K}}
$$

where: $\mathrm{C}_{\mathrm{Ra}}, \mathrm{C}_{\mathrm{Th}}$ and $\mathrm{C}_{\mathrm{K}}$ are the specific activities (Bq/kg dry weight) of ${ }^{226} \mathrm{Ra},{ }^{232} \mathrm{Th}$ and ${ }^{40} \mathrm{~K}$, respectively.

\subsection{Absorbed Dose Rate and Annual Effective Dose}

The measured activity of ${ }^{226} \mathrm{Ra},{ }^{232} \mathrm{Th}$ and ${ }^{40} \mathrm{~K}$ were converted into doses by applying the factors $0.4551,0.5835$ and $0.0429\left(\mathrm{nGyh}^{-1} / \mathrm{Bqkg}^{-1}\right)$ for radium, thorium and potassium, respectively. These factors were used to calculate the total absorbed gamma dose rate in air at $1 \mathrm{~m}$ above the ground level using the following equation [10]:

$$
\mathrm{D}_{\mathrm{R}}(\mathrm{nGy} / \mathrm{h})=0.4551 \mathrm{C}_{\mathrm{Ra}}+0.5835 \mathrm{C}_{\mathrm{Th}}+0.0429 \mathrm{C}_{\mathrm{K}}
$$

where: $\mathrm{C}_{\mathrm{Ra}}, \mathrm{C}_{\mathrm{Th}}$ and $\mathrm{C}_{\mathrm{K}}$ are the activity concentrations $(\mathrm{Bq} / \mathrm{kg})$ of ${ }^{226} \mathrm{Ra},{ }^{232} \mathrm{Th}$ and ${ }^{40} \mathrm{~K}$, respectively.

Annual estimated average effective dose equivalent received by a member is calculated using a conversion factor of $0.7 \mathrm{~Sv} / \mathrm{Gy}$, which is used to convert the absorbed dose rate to annual effective dose with an outdoor occupancy of $20 \%$ [10]:

$$
\mathrm{D}_{\text {eff }}(\mathrm{mSv} / \mathrm{y})=\mathrm{D}(\mathrm{nGy} / \mathrm{h}) \times 8760(\mathrm{~h} / \mathrm{y}) \times 0.7(\mathrm{~Sv} / \mathrm{Gy}) \times 0.2 \times 10^{-6}
$$

\subsection{External Hazard Index and Internal Hazard Index}

In the literature a number of criterion formulae have been derived over the years to assess the radiation dose rate due to exposure to gamma radiation from the natural radionuclides contained in soil. To limit the annual external gamma-ray dose to $1.5 \mathrm{~Gy}$ for the samples under investigation [10], the external hazard index $\left(\mathrm{H}_{\mathrm{ex}}\right)$ is given by the equation:

$$
\mathrm{H}_{\mathrm{ex}}=\left(\mathrm{C}_{\mathrm{Ra}} / 370+\mathrm{C}_{\mathrm{Th}} / 259+\mathrm{C}_{\mathrm{K}} / 4810\right)
$$

where: $\mathrm{C}_{\mathrm{Ra}}, \mathrm{C}_{\mathrm{Th}}$ and $\mathrm{C}_{\mathrm{K}}$ are the activity concentrations in $\mathrm{Bq} / \mathrm{kg}$ of ${ }^{226} \mathrm{Ra},{ }^{232} \mathrm{Th}$ and ${ }^{40} \mathrm{~K}$ Respectively. The value of this index must be less than unity for the radiation hazard to be negligible.

The internal exposure to ${ }^{222} \mathrm{Rn}$ and its radioactive progeny is controlled by the internal hazard index $\left(\mathrm{H}_{\mathrm{in}}\right)[10]$, which is given by the equation:

$$
\mathrm{H}_{\mathrm{in}}=\mathrm{C}_{\mathrm{Ra}} / 185+\mathrm{C}_{\mathrm{Th}} / 259+\mathrm{C}_{\mathrm{K}} / 4810
$$

where: $\mathrm{C}$ denotes the respective specific activity in $\mathrm{Bq} / \mathrm{kg}$, for the safety, $\mathrm{H}_{\text {in }}$ should be less than unity.

\subsection{Representative Level Index $\left(\mathrm{I}_{\gamma \mathrm{r}}\right)$}

Representative level index $\left(\mathrm{I}_{\gamma \mathrm{r}}\right)$ is used to estimate the level of $\gamma$-radiation hazard associated with the natural radionuclides in specific building materials, is defined as [4] [10]:

$$
\mathrm{I}_{\gamma \mathrm{r}}=\mathrm{C}_{\mathrm{Ra}} / 150+\mathrm{C}_{\mathrm{Th}} / 100+\mathrm{C}_{\mathrm{k}} / 1500
$$

where: $\mathrm{C}_{\mathrm{Ra}}, \mathrm{C}_{\mathrm{Th}}$ and $\mathrm{C}_{\mathrm{k}}$ are the activity concentrations of ${ }^{226} \mathrm{Ra},{ }^{232} \mathrm{Th}$ and ${ }^{40} \mathrm{~K}$ in $\mathrm{Bq} / \mathrm{k}$, respectively.

\section{Results and Discussion}

\subsection{XRD Analysis}

$\mathrm{X}$-ray diffraction is a non-destructive analytical technique, which provides detailed information about the atomic structure of crystalline substances, chemical composition, and physical properties of materials. In the present 
study, the XRD results indicate that the main major, minor and trace constituents varied from one sample to another, as shown in Figure 2(a), Figure 2(b), and in Table 2. The major element defines the samples and has the highest concentrations. In sample soil1, Calcium Thorium Phosphate is the major in XRD spectrum Figure 2(a), Figure 2(b). While, trace elements occur in small concentrations (usually measured in ppm). They do not change the essence of what a material is and minor elements are in between major and trace elements. XRD spectrum Figure 2(a), Figure 2(b), shows that Thorium (V) sulfide and Thorium are minor and trace elements in sample 1 respectively.

Table 3 is a review of the chemical composition of each mineral and its description which reflects the condition of its formation [13].

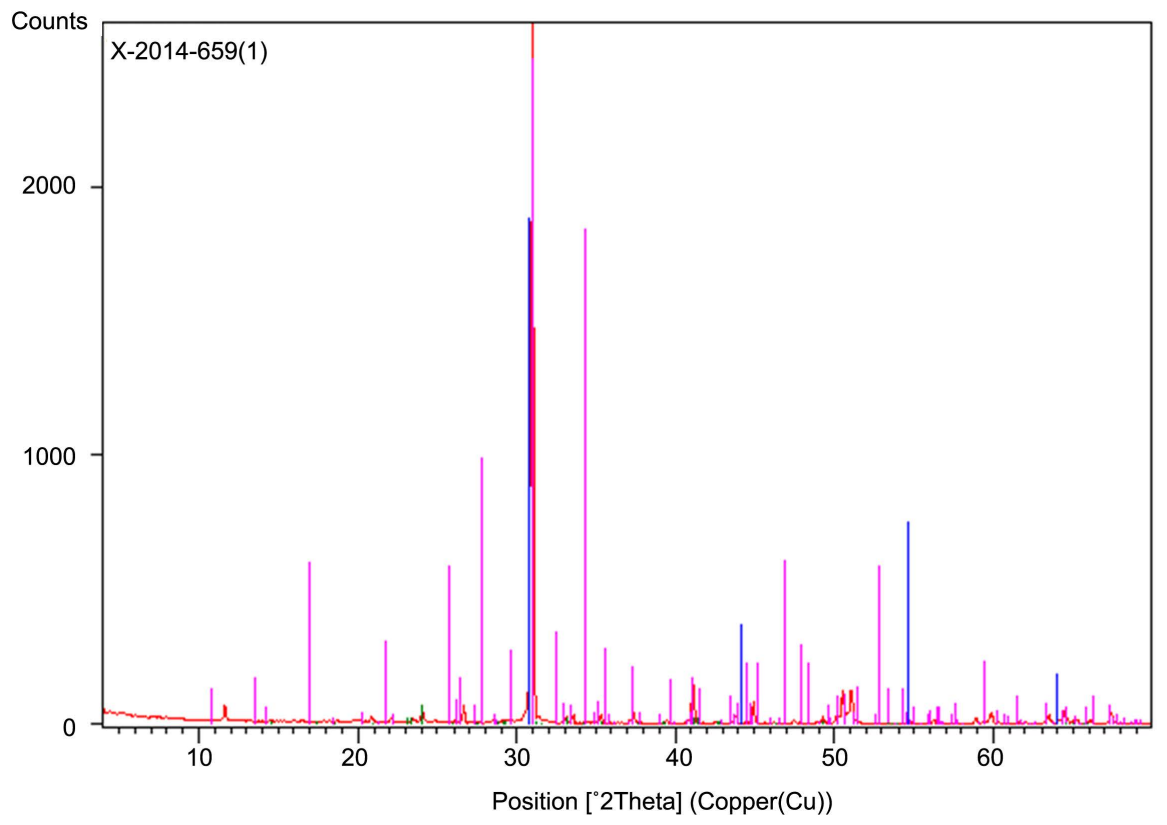

(a)

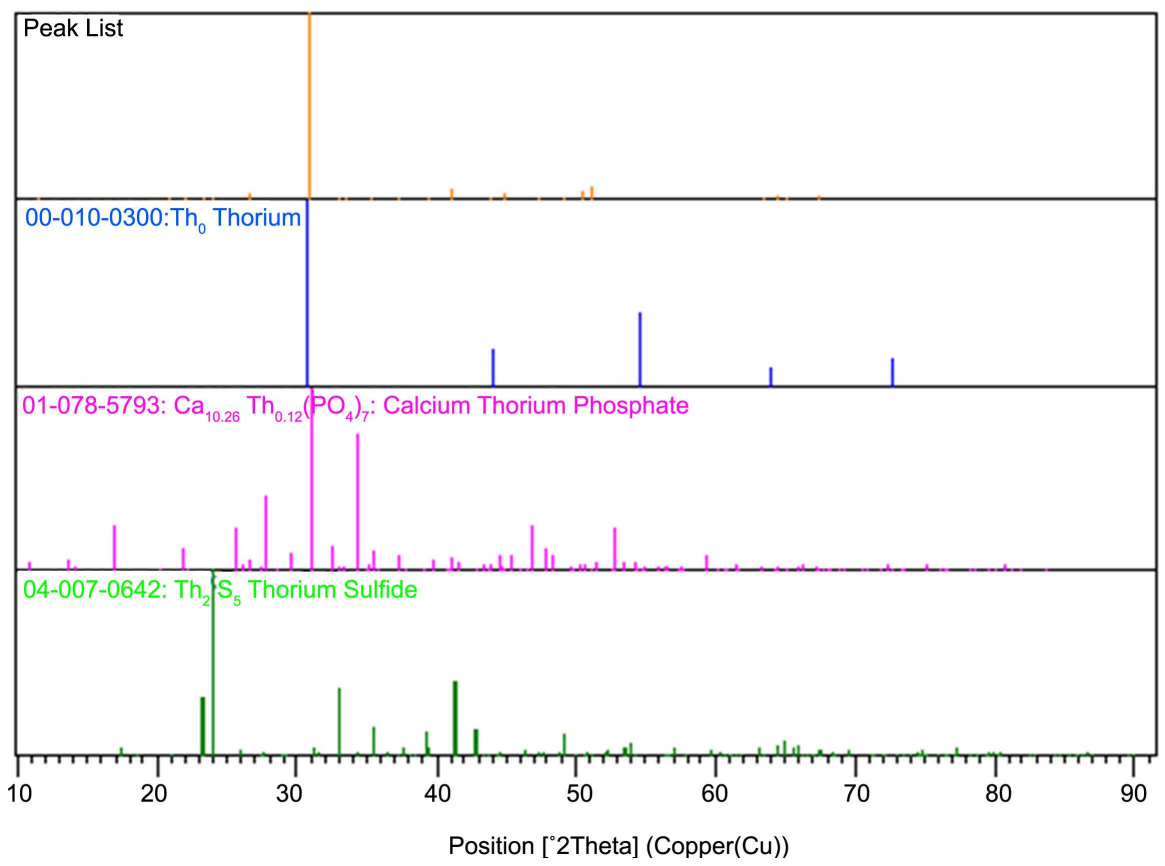

(b)

Figure 2. (a) XRD spectrum of sample soil 1; (b) XRD measurement of sample soil 1. 
Table 2. The compound Name of mineral constituents of 10 samples analyzed by XRD spectrometer.

\begin{tabular}{|c|c|c|c|}
\hline Sample code & MAJOR & MINOR & TRACE \\
\hline Soil 1 & $\begin{array}{l}\text { Calcium Thorium Phosphate } \\
\text { (Whitlockite-type) }\end{array}$ & thorium(V) sulfide & Thorium \\
\hline Soil 2 & $\begin{array}{l}\text { Thorium Oxide Phosphate } \\
\text { Thorium germanide }\end{array}$ & $\begin{array}{l}\text { Sodium Beryllium Thorium } \\
\text { Fluoride Na Cesium Thorium Fluoride }\end{array}$ & Thorium \\
\hline Soil 3 & $\begin{array}{l}\text { Uranium Oxide Sulfide Uranium } \\
\text { Fluoride }\end{array}$ & Uranium Arsenic & Uranium \\
\hline Soil 4 & Uranium Imide & Copper Uranium Oxide & Uranium \\
\hline Soil 5 & Thorium Rhodium Boride & $\begin{array}{l}\text { Uranium Ytterbium Sulfide Oxide Nickel } \\
\text { Vanadium Uranium Oxide Hydrate }\end{array}$ & Thorium \\
\hline Soil 6 & $\begin{array}{l}\text { Thorium Selenium Uranium Boron } \\
\text { Chloride Urea Hydrate }\end{array}$ & $\begin{array}{l}\text { Thorium Carbide Uranium } \\
\text { Phosphoryl Chloride }\end{array}$ & Thorium \\
\hline Soil 7 & Uranium Imide Chloride & Thorium Arsenic & $\begin{array}{l}\text { Uranium Uranyl Sulfate } \\
\text { Hydroxide Hydrate (Uranopilite) }\end{array}$ \\
\hline Soil 8 & ----- & ------- & $\begin{array}{l}\text { Uranium Thulium Thorium } \\
\text { Iodide }\end{array}$ \\
\hline Soil 9 & $\begin{array}{l}\text { Nickel Vanadium Uranium Oxide } \\
\text { Hydrate (Meta-autunite) }\end{array}$ & $\begin{array}{l}\text { Uranium Arsenide Sulfide Uranium Fluoride Hy- } \\
\text { drate }\end{array}$ & Uranium \\
\hline Soil 10 & $\begin{array}{l}\text { Uranium Chromium Selenium } \\
\text { (Hidalgoite) }\end{array}$ & Aluminum Uranium & $\begin{array}{l}\text { Uranium Barium Uranium } \\
\text { Gadolinium Oxide }\end{array}$ \\
\hline
\end{tabular}

Table 3. The Compound name/Chemical composition and description.

\begin{tabular}{|c|c|}
\hline Compound name/Chemical composition & Description \\
\hline $\begin{array}{l}\text { Calcium Thorium Phosphate (Whitlockite-type) } \mathrm{Ca}_{10.26} \\
\qquad \mathrm{Th}_{0.12}\left(\mathrm{PO}_{4}\right)_{7}\end{array}$ & Synthesis and new crystal structure refinement. \\
\hline Thorium(V) sulfide- $\mathrm{Th}_{2} \mathrm{~S}_{5}$ & $\begin{array}{l}\text { An inorganic chemical compound composed of two thorium } \\
\text { atom ionically bonded to five atoms of sulfur. }\end{array}$ \\
\hline Thorium-Th & Chemical element and radioactive actinide metal. \\
\hline Thorium Oxide Phosphate- $\mathrm{Th}_{2}\left(\mathrm{PO}_{4}\right)_{2} \mathrm{O}$ & The compound was synthesized under wet hydrothermal conditions. \\
\hline Thorium germanide- $\mathrm{Th}_{3} \mathrm{Ge}_{2}$ & Compound composed of Th(rare earth), Ge(Metalloid). \\
\hline Sodium Beryllium Thorium Fluoride-NaBeTh${ }_{3} \mathrm{~F}_{15}$ & $\begin{array}{c}\text { An inorganic chemical compound with one } \mathrm{Na} \text {, and Be , three } \\
\text { Th atom ionically bonded to fifteen } \mathrm{F} \text {. }\end{array}$ \\
\hline Cesium Thorium Fluoride-CsTh ${ }_{6} \mathrm{~F}_{25}$ & $\begin{array}{l}\text { Compound composed of Cs(Alkali Earth), Th(rare earth), and F } \\
\text { (Metalloids). }\end{array}$ \\
\hline Uranium Oxide Sulfide-UOS & $\begin{array}{l}\text { Compound composed of U (rare earth), O (Non-Metals), and } \\
\text { S (Non-Metals). }\end{array}$ \\
\hline Uranium Fluorid-UF 4 & $\mathrm{UF}_{4}$ is a solid composed of particles with a texture and soluble in water. \\
\hline Uranium Arsenic- $\mathrm{U}_{3} \mathrm{As}_{4}$ & Compound composed of U (rare earth), and As ((Metalloid). \\
\hline Uranium-U & Uranium is heavy metal. In nature, uranium is found as an xide. \\
\hline Copper Uranium Oxide- $\mathrm{CuU}_{3} \mathrm{O}_{10}$ & $\begin{array}{l}\text { Compound composed of } \mathrm{Cu} \text { (Transition Metals), U(rare earth), } \\
\text { and O (Non-metal) }\end{array}$ \\
\hline Thorium Rhodium Boride $\mathrm{Th} \mathrm{Rh}_{4} \mathrm{~B}_{4}$ & This compound composed of Th, Rh, B. \\
\hline Uranium Ytterbium Sulfide Oxide- $\mathrm{U}_{2} \mathrm{YbS}_{3} \mathrm{O}_{2}$ & Compound composed of U, Yb, S, O \\
\hline Nickel Vanadium Uranium Oxide Hydrate $\mathrm{Ni}\left(\mathrm{VUO}_{6}\right)_{24} \mathrm{H}_{2} \mathrm{O}$ & $\begin{array}{l}\text { This compound contains U (RARE EARTH), Ni and V } \\
\text { (transition Metals), H, O ((Non-metal). }\end{array}$ \\
\hline Thorium Selenium- $\mathrm{Th}_{7} \mathrm{Se}_{12}$ & Seven atoms of Th and twelve atoms of Se bonded. \\
\hline $\begin{array}{l}\text { Uranium Boron Chloride Urea Hydrate } \\
\qquad \mathrm{U}\left(\mathrm{B}_{12} \mathrm{Cl}_{12}\right)_{2} \cdot 8 \mathrm{Co}\left(\mathrm{NH}_{2}\right)_{2} \cdot 2 \mathrm{H}_{2} \mathrm{O}\end{array}$ & Compound composed of U, B, Cl, Co, N, H, AND O. \\
\hline
\end{tabular}




\section{Continued}

Thorium Carbide-ThC 2

Uranium Phosphoryl Chloride- $\mathrm{U}_{3}(\mathrm{PO})_{6} \mathrm{Cl}_{32}$

Thorium Arsenic-ThAs

Uranium Imide Chloride-U(NH)Cl

Uranyl Sulfate Hydroxide Hydrate (Uranopilite) $\left(\mathrm{UO}_{2}\right)_{6}\left(\mathrm{SO}_{4}\right)(\mathrm{OH})_{10} \cdot 12 \mathrm{H}_{2} \mathrm{O}$

Thorium Thulium Iodide-Th $\mathrm{TmI}_{6}$

(Meta autunite)-Ca( $\left(\mathrm{UO}_{2}\right)_{2}\left(\mathrm{PO}_{4}\right)_{2} \cdot 4\left(\mathrm{H}_{2} \mathrm{O}\right)$

Uranium Arsenide Sulfide- $\mathrm{U}_{2}$ AsS

Uranium Fluoride Hydrate- $\mathrm{UF}_{4}\left(\mathrm{H}_{2} \mathrm{O}\right)_{0.7}$

Uranium Chromium Selenium-UCrSe

(Hidalgoite)- $\mathrm{PbAl}_{3} \mathrm{AsO}_{4} \mathrm{SO}_{4}(\mathrm{OH})_{6}$

Aluminum Uranium-UA $\mathrm{UA}_{13}$
Thorium carbide structure.

Compound composed of U, P, O, Cl.

Compound composed of Th (rare earth) and As (Metalloid).

Compound composed of $\mathrm{U}$ and $(\mathrm{NH}) \mathrm{Cl}$ (Volcanic fumaroles, burning coal seams and quano deposits).

Secondary mineral found on altering uraninite.

Compound composed of Th (rare earth), Tm (rare earth), and I (Metalloids).

Associated with autunite in fractures in uraniferous igneous rocks.

Compound composed of U (rare earth), As (Metalloid), and S (Non-Metal).

Uranium tetrafluoride (UF4) and water vapor.

Compound composed of U (rare earth), Cr (Transition Metal), and Se (Non-Metal).

Secondary mineral of the oxide zone of polymetallic sulfide deposits. Inorganic compound composed of $\mathrm{U}$ and $\mathrm{Al}$.

Chemical compound composed of Be, U, Gd, and O.

\subsection{Gamma Analysis}

\subsubsection{Radionuclide Activity Concentration}

Table 4 represents the concentrations in $\mathrm{Bq} / \mathrm{kg}$ of the different radionuclides in the samples. The radioactivity of the samples, as shown in Table 4, for Ra-226 ranged from $57.03 \mathrm{~Bq} / \mathrm{kg}$ (sample 3) to $4220.41 \mathrm{~Bq} / \mathrm{kg}$ (sample 2) with average value $1104.14 \mathrm{~Bq} / \mathrm{kg}$. Meanwhile; for Th-232 series the lowest value was13.55 Bq/kg (sample 5) and the highest value was $130.46 \mathrm{~Bq} / \mathrm{kg}$ (sample 10) with an average value $74.21 \mathrm{~Bq} / \mathrm{kg}$, for K-40 activities ranged from $12.18 \mathrm{~Bq} / \mathrm{kg}$ (sample 3) to $948.93 \mathrm{~Bq} / \mathrm{kg}$ (sample 1) with average value $455.80 \mathrm{~Bq} / \mathrm{kg}$. In general, all the existed results were higher than the given values by UNSCEAR 2000 as: $\left(35 \mathrm{~Bq} / \mathrm{Kg}\right.$ for $\left.{ }^{226} \mathrm{Ra}\right),(30 \mathrm{~Bq} / \mathrm{kg}$ for $\left.{ }^{232} \mathrm{Th}\right)$ and $\left(400 \mathrm{~Bq} / \mathrm{kg}\right.$ for ${ }^{40} \mathrm{~K}$, except samples 3, 5, and 6 of ${ }^{232} \mathrm{Th}$ and samples 2, 3, 5, and 6 of ${ }^{40} \mathrm{~K}$. The Ra226 activity concentrations of the samples are higher than those of Th-232 and K-40. The high concentrations results of ${ }^{238} \mathrm{U}$ in these areas of Sinai are due to the presence of phosphate and granite rocks with highly enriched with this radioactive nuclide and the weathering effects [15].

\subsubsection{Hazard Indices}

As shown in Table 5, the average values of radium equivalent $\left(\mathrm{Ra}_{\mathrm{eq}}\right)$, Hazard indices $\left(\mathrm{H}_{\mathrm{ex}}\right.$ and $\left.\mathrm{H}_{\mathrm{in}}\right)$, Gamma index $\left(I_{\gamma r}\right)$, the total dose rate $\left(D_{R}\right)$, And Annual effective Dose $\left(D_{\text {eff }}\right)$ were $1245.37 \mathrm{~Bq} / \mathrm{Kg}, 3.37,6.35,8.41$, $537.30(\mathrm{nGy} / \mathrm{h})$, and $0.6589(\mathrm{mSv} / \mathrm{y})$ respectively. These average values were very high compared to the world standard values as given by UNSCEAR 2000. Based on these results of Hazard, one can deduce that the use of soil samples for construction of the dwellings is considered to be not safe for human habitation.

\section{Conclusions}

The results of the present work indicate that:

- XRD measurements show that the major, minor, and some of trace elements concentrations for the samples are uranium compounds and thorium compounds.

- The study area shows very high values of ${ }^{238} \mathrm{U}$ and ${ }^{232} \mathrm{Th}$ concentrations except sample 3 . Also, ${ }^{40} \mathrm{~K}$ has high concentrations except sample 3 and 5.

- These average values for the soil samples from these regions (Jabal Al Qur, Wadi Baba, and Wadi Sieh) are considered to be very high levels of radioactivity compared to the world standard.

- The average of absorbed dose rate, annual effective dose, radium equivalent, and the radioactivity hazard in- 
Table 4. The specific radioactive concentrations in $\mathrm{Bq} / \mathrm{kg}$, dry weight for Sinai samples.

\begin{tabular}{cccc}
\hline \multirow{2}{*}{ Sample code } & \multicolumn{2}{c}{ Radioactivity concentration $(\mathrm{Bq} / \mathrm{kg})$} & ${ }^{40} \mathrm{~K}$ \\
\cline { 2 - 3 } & ${ }^{226} \mathrm{Ra}$ & ${ }^{232} \mathrm{Th}$ & $948.93 \pm 0.0004$ \\
Soil 1 & $591.34 \pm 0.0005$ & $100.22 \pm 0.001$ & $248.65 \pm 0.0006$ \\
Soil 2 & $4220.41 \pm 0.0004$ & $77.22 \pm 0.001$ & $12.18 \pm 0.0004$ \\
Soil 3 & $57.03 \pm 0.0004$ & $15.30 \pm 0.001$ & $569.67 \pm 0.0005$ \\
Soil4 & $704.21 \pm 0.0005$ & $82.53 \pm 0.002$ & $54.79 \pm 0.0006$ \\
Soil 5 & $1571.29 \pm 0.0004$ & $13.55 \pm 0.002$ & $172.72 \pm 0.0005$ \\
Soil 6 & $560.76 \pm 0.0005$ & $23.66 \pm 0.002$ & $569.14 \pm 0.0005$ \\
Soil 7 & $779.30 \pm 0.0006$ & $87.21 \pm 0.002$ & $654.47 \pm 0.0005$ \\
Soil 8 & $1250.81 \pm 0.0005$ & $125.57 \pm 0.002$ & $641.97 \pm 0.0004$ \\
Soil 9 & $381.36 \pm 0.0005$ & $86.44 \pm 0.002$ & $685.53 \pm 0.0005$ \\
Soil 10 & $924.90 \pm 0.0005$ & $130.46 \pm 0.002$ & $12.18-948.93$ \\
Range & $57.03-4220.41$ & $13.55-130.46$ & 74.21 \\
Average & 1104.14 & & 455.80 \\
\hline
\end{tabular}

Table 5. The radium equivalent $\mathrm{Ra}_{\mathrm{eq}}(\mathrm{Bq} / \mathrm{kg})$, Dose rate $\mathrm{D}_{\mathrm{R}}$ outdoor $(\mathrm{nGy} / \mathrm{h})$, annual effective Dose (mSv/y and hazard indices for the samples.

\begin{tabular}{|c|c|c|c|c|c|c|}
\hline Sample code & $\begin{array}{c}\text { Radium } \\
\text { equivalent } \\
\text { Raeq }(\mathrm{Bq} / \mathrm{kg})\end{array}$ & External index & $H_{e x}$ Internal index $H_{i n}$ & $\begin{array}{c}\text { Gamma index } \\
\mathbf{I}_{\gamma \mathrm{r}}\end{array}$ & $\begin{array}{c}\text { Dose rate } \\
\text { D }_{\mathrm{R}} \text { outdoor } \\
\text { (nGy/h) }\end{array}$ & $\begin{array}{l}\text { Annual effective } \\
\text { Dose } D_{\text {eff }}(\mathrm{mSv} / \mathrm{y})\end{array}$ \\
\hline Soil 1 & 807.74 & 2.18 & 3.78 & 5.58 & 355.75 & 0.4363 \\
\hline Soil 2 & 4349.98 & 11.76 & 23.16 & 29.07 & 1860.91 & 2.282 \\
\hline Soil 3 & 79.85 & 0.22 & 0.37 & 0.541 & 34.41 & 0.0422 \\
\hline Soil 4 & 866.08 & 2.34 & 4.24 & 5.9 & 376.60 & 0.4619 \\
\hline Soil 5 & 1594.88 & 4.31 & 8.56 & 10.65 & 681.73 & 0.8361 \\
\hline Soil 6 & 607.88 & 1.64 & 3.16 & 4.09 & 261.61 & 0.3208 \\
\hline Soil 7 & 947.83 & 2.56 & 4.67 & 6.45 & 411.57 & 0.5047 \\
\hline Soil 8 & 1480.77 & 4.00 & 7.38 & 10.03 & 640.47 & 0.7855 \\
\hline Soil 9 & 554.39 & 1.5 & 2.53 & 3.83 & 244.29 & 0.2996 \\
\hline Soil 10 & 1164.24 & 3.15 & 5.65 & 7.93 & 505.69 & 0.6202 \\
\hline Average & 1245.37 & 3.37 & 6.35 & 8.41 & 537.30 & 0.6589 \\
\hline World standard & 370 & $\leq 1$ & $\leq 1$ & $\leq 1$ & 57 & 0.07 \\
\hline
\end{tabular}

dices values are much higher than the corresponding world average.

- Precautions and recommendations should be taken into consideration for high levels of radioactivity concentrations in these samples especially when people may inhabit in these areas. I recommend that this study to be taken as a base line for any future studies in this area.

\section{References}

[1] Beck, H.L. (1972) Physics of Environmental Gamma Radiation Fields. The Natural Radiation Environment 2, USERDA Report CON-720805-P2, 101-134. 
[2] Baldık, R., Aytekin, H. and Erer, M. (2011) Radioactivity Measurements and Radiation Dose Assessments Due to Natural Radiation in Karabük (Turkey). Journal of Radioanalytical and Nuclear Chemistry, 289, 297-302. http://dx.doi.org/10.1007/s10967-011-1077-z

[3] Tufail, M., Iqbal, M. and Mirza, S. (2000) Radiation Doses Due to the Natural Radioactivity in Pakistan Marble. Radioprotection, 35, 299-310. http://dx.doi.org/10.1051/radiopro:2000110

[4] El-Mageed, A.A., et al. (2011) Assessment of Natural and Anthropogenic Radioactivity Levels in Rocks and Soils in the Environments of Juban Town in Yemen. Radiation Physics and Chemistry, 80, 710-715. http://dx.doi.org/10.1016/j.radphyschem.2011.02.025

[5] Patra, A., et al. (2013) Distribution of Radionuclides in Surface Soils, Singhbhum Shear Zone, India and Associated Dose. Environmental Monitoring and Assessment, 185, 7833-7843. http://dx.doi.org/10.1007/s10661-013-3138-y

[6] Al-Ghamdi, A. (2014) Natural Radioactivity Measurements for Assessment Radiation Hazards from Surface Soil of Industrial Yanbu City, Saudi Arabia. Life Science Journal, 11, 1123-1130.

[7] Bala, P., Mehra, R. and Ramola, R. (2014) Distribution of Natural Radioactivity in Soil Samples and Radiological Hazards in Building Material of Una, Himachal Pradesh. Journal of Geochemical Exploration, 142, 11-15. http://dx.doi.org/10.1016/j.gexplo.2014.02.010

[8] Mehra, R. and Bala, P. (2014) Assessment of Radiation Hazards Due to the Concentration of Natural Radionuclides in the Environment. Environmental Earth Sciences, 71, 901-909. http://dx.doi.org/10.1007/s12665-013-2493-x

[9] Sarap, N.B., et al. (2014) Environmental Radioactivity in Southern Serbia at Locations Where Depleted Uranium Was Used. Archives of Industrial Hygiene and Toxicology, 65, 189-197. http://dx.doi.org/10.2478/10004-1254-65-2014-2427

[10] Radiation, U.N.S.C.o.t.E.o.A. (2000) UNSCEAR 2000. Sources and Effects of Ionizing Radiation, 2.

[11] Fultz, B. and Howe, J. (2013) Diffraction and the X-Ray Powder Diffractometer. Transmission Electron Microscopy and Diffractometry of Materials, Springer, 1-57. http://dx.doi.org/10.1007/978-3-642-29761-8_1

[12] Abbady, A.G. (2004) Estimation of Radiation Hazard Indices from Sedimentary Rocks in Upper Egypt. Applied Radiation and Isotopes, 60, 111-114.

[13] Orlova, A.I., et al. (2009) Calcium Thorium Phosphate (Whitlockite-Type Mineral). Synthesis and Structure Refinement. Crystallography Reports, 54, 591-597.

[14] Álvaro, T., et al. (2005) Outcome in Hodgkin’s Lymphoma Can Be Predicted from the Presence of Accompanying Cytotoxic and Regulatory T Cells. Clinical Cancer Research, 11, 1467-1473.

[15] Marouf, B., et al. (1992) Population Doses from Environmental Gamma Radiation in Iraq. Health Physics, 62, 443444. 